\title{
Teknologi Blended Learning dalam Meningkatkan Kemampuan Bahasa Inggris Siswa Sekolah Menengah Pertama (SMP)
}

\author{
Syaadiah Arifin ${ }^{1}$, Hamzah Puadi Ilyas $^{2}$, Aida Fitri Ani ${ }^{3}$ \\ Penulis Pertama*)1, Penulis Kedua ${ }^{2}$ \\ 12Universitas Muhammadiyah Prof. Dr. Hamka-Jakarta 1 \\ ${ }^{3}$ Universitas Muhammad Husni Thamrin-Jakarta 2 \\ *)Corresponding author, $\equiv$ : syaadiah.arifin@uhamka.ac.id
}

(Di isi oleh editor)

Revisi 13/06/2019;

Diterima 18/07/2019;

Publish 08/08/2019

Kata kunci: blended learning, Applikasi Line, English teaching c

\begin{abstract}
Abstrak
Pada saat ini teknologi berkembang dengan sangat pesat. Perkembangan ini dapat dimanfaatkan guru untuk kegiatan pembelajaran melalui teknologi Blended Learning. Salah satu bentuk dari teknologi ini adalah melalui M-Learning (Mobile Learning) yang dapat membantu siswa untuk belajar di mana saja dan kapan saja. Penyuluhan ini diadakan di daerah Cilamaya Jawa Barat sekitar $150 \mathrm{~km}$ dari Jakarta. Pesertanya berjumlah 8 orang guru dari berbagai SMP. Tujuan utama dari Pengmas ini adalah untuk memberikan penyuluhan penggunaan aplikasi yang terdapat dalam telepon genggam yaitu Line untuk meningkatkan kemampuan Bahasa Inggris siswa. Instrumen yang digunakan pada kegiatan ini adalah: Power Point, contoh Rpp/ lesson plan, dan diskusi interaktif. Pada penyuluhan dihari kedua peserta diharuskan membawa contoh RPP/ lesson plan sederhana yang mereka buat sendiri dan akan dipraktekan di aplikasi Line. Melalui program pelatihan ini diharapkan guru dapat menyelesaikan bahan mata pelajaran tepat waktu dan memberikan tambahan pelajaran dengan cara yang lebih menarik dan interaktif. Para peserta pelatihan tidak mengalami kesulitan memahami apa yang sudah dijelaskan oleh nara sumber mengenai pembuatan RPP/ lesson plan. Peserta antusias dalam mengikuti semua kegiatan dan akan mempraktekannya dalam mengajar.
\end{abstract}




\section{Suluah Bendang: Jurnal Ilmiah Pengabdian Kepada Masyarakat}

Vol.19, No.3, 2019

Syaadiah Arifin1, Hamzah Puadi llyas2, Aida Fitri Ani3

\section{PENDAHULUAN}

\section{Analisis Situasi}

Istilah Blended Learning sudah mulai digunakan semenjak tahun 1999 (Friesen, 2012).Teknologi ini memiliki potensi untuk menjembatani ruang, waktu serta fleksibilitas siswa dalam proses belajar mereka. Konsep dari Blended Learning sendiri tidak dapat didefinisikan secara tepat. Hal ini dikarenakan setiap peneliti mempunyai perspektif yang berbeda mengenai istilah ini. Akan tetapi semua peneliti setuju jika Blended Learning mengacu kepada pengalaman belajar yang terintegrasi dibawah pengawasan dan bimbingan guru dalam bentuk tatap muka maupun kehadiran secara virtual (Bryan \& Volchenkova, 2016).

Salah satu bentuk dari pengajaran dengan menggunakan teknologi Blended Learning adalah dengan menggunakan aplikasi yang ada di telepon genggam atau Mobile-Phone. Pada saat ini penggunaan telepon genggam dikalangan para pelajar di Indonesia bukan sesuatu yang hal baru. Pada umumnya mereka menggunakan telepon genggam untuk beberapa keperluan seperti mengunduh dan mendengarkan lagu, menghubungi teman, menonton film (streaming), berfoto/ swafoto, dan bermain games. Sebagian besar penggunaan telepon genggam dikalangan remaja untuk bersenang-senang. Sudah saatnya bagi para remaja menggunakan telepon genggam untuk hal-hal yang lebih bermanfaat seperti mencari informasi yang dibutuhkan yang berkaitan dengan pelajaran, membaca berita penting dari manca negara, dan yang lebih penting lagi adalah sebagai sarana belajar.

Pembelajaran melalui Mobile-Learning (M-Learning) adalah pembelajaran yang unik dan cukup efektif dikarenakan para peserta didik dapat mengakses materi, mengerjakan latihan dan mengirimkan hasil latihan kapanpun dan dimanapun mereka berada (Tamimuddin, 2017). Kelebihan M-Learning yang lain adalah pelajar dapat membawa telepon genggam kemanapun mereka pergi sehingga mereka mempunyai waktu yang fleksibel dalam belajar. Ada beberapa aplikasi yang ada di telepon genggam yang dapat digunakan untuk media pembelajaran, seperti: Line, WhatsApp, Messenger, Telegram, dan ada banyak lagi yang lain. Dibandingkan dengan aplikasi lain, Line memiliki beberapa keunggulan, salah satunya adalah fasilitas Video Call yang juga ada di aplikasi sosial media lainnya. Akan tetapi jika dibandingkan dengan applikasi lainnya, fasilitas Video Call dari Line lebih ringan dan jarang sekali terjadi buffering. Keunggulan aplikasi Line lainnya adalah dapat memuat group chat yang lebih banyak, dan dapat digunakan untuk mengirim pesan sekaligus ke semua pengguna Line yang menambahkan sebagai teman melalui aplikasi ini (Ramadan, 2018).

Oleh karena itulah penulis tertarik untuk memberikan pelatihan singkat guru-guru SMP di Cilamaya untuk menggunakan teknologi ini sebagai salah satu sarana pengajaran. Berdasarkan hasil kuestioner yang diberikan kepada siswa kelas IX, hampir semua siswa mempunyai telpon genggam, walaupun mereka tidak membawanya ke sekolah karena adanya peraturan yang melarang mereka membawa telpon genggam. Hasil wawancara dari beberapa guru, mereka sulit menyelesaikan materi tepat waktu. Hal ini disebabkan oleh beberapa hal diantaranya adalah terpotong libur nasional (tanggal merah), guru yang harus menghadiri rapat atau pelatihan dari sekolah, kegiatan internal yang melibatkan para pelajar sehingga melewatkan beberapa mata pelajaran termasuk bahasa Inggris. Biasanya jika guru berhalangan untuk mengajar hanya maka memberikan tugas kepada siswa untuk mengerjakan soal-soal yang sudah disiapkan.

Pelajaran bahasa Inggris di Sekolah Menengah Pertama pada umumnya diberikan seminggu dua kali. Setiap pertemuan diadakan selama 2 jam (1 jam=45 menit). Materi yang diberikan cukup banyak mencakup: listening, speaking, reading dan writing. Jika mengerjakan semua latihan di kelas kendalanya adalah waktu yang terbatas. 
Disamping itu materi-materi pembelajaran bahasa Ingris untuk tingkat SMP (Sekolah Menegah Pertama) bisa dikatakan sederhana. Permasalahannya, ketika para peserta didik mengerjakan soal-soal USBN (Ujian Sekolah Bersama Nasional) dan UNBK (Ujian Nasional Berbasis Komputer) mereka cukup mendapat kesulitan dalam mengerjakan soal-soal tersebut dikarenakan buku-buku materi pengajaran bahasa Inggris dan latihan dari LKS yang mereka dapat dari sekolah tidak sesulit dan sesederhana dengan soal-soal yang diujikan di USBN dan UNBK. Untuk mengatasi persoalan ini guru akan memberikan latihan tambahan mengacu kepada soal-soal yang diujikan pada USBN dan UNBK melalui aplikasi LINE

\section{Solusi dan Target}

Sebelum melaksanakan Pengabdian Kepada Masyarakat (PKM), Tim PKM mengadakan survey ke lokasi yang akan diadakan kegiatan PKM untuk mengetahui permasalahan yang dihadapi oleh guru Sekolah Menengah Pertama yang letaknya cukup jauh dari pusat kota. Lokasi yang dipilih adalah daerah Cilamaya-Kerawang sekitar $150 \mathrm{~km}$ dari Jakarta. Ada 3 tahapan utama yang dilaksanakan

Tahap Awal (Tahap Persiapan)

Diadakan wawancara kepada beberapa guru pengampu bahasa Inggris dari berbagai sekolah menengah pertama di daerah Cilamaya- Karawang diantaranya: SMP Babusallam Cilamaya, SMP Al Kautsar Cilamaya Wetan, SMPN I Cilamaya, dan SMP Muhammadiyah Cikampek mengenai kendala-kendala yang mereka hadapi ketika mengajar bahasa Inggris. Kendala utama adalah sulit untuk menyelesaikan bahan ajar tepat waktu, atau dapat menyelesaikan bahan ajar dengan terburu buru karena waktu yang terbatas. Hal ini disebabkan oleh karena guru mendapat tugas dari sekolah ataupun terpotong tanggal merah, dan berbagai kegiatan lainnya. Tim kemudian memutuskan untuk memberikan alternatif pengajaran tambahan melalui salah satu aplikasi telpon genggam yaitu LINE. Untuk mengetahui apakah siswa memiliki telpon genggam diadakanlah wawancara singkat kepada siswa kelas IX apakah mereka mempunyai telpon genggam. Pada umumnya mereka memiliki perangkat ini, paling tidak anggota keluarga lain memilikinya.

Tahap Pelaksanaan

Tim pengmas mengadakan wawancara kepada beberapa guru apakah mereka menggunakan salah satu aplikasi telepon genggam. Jawaban guru adalah mereka mengenal aplikasi LINE bahkan sudah menggunakannya cukup lama. Pertanyaan selanjutnya adalah apakah telepon genggam ini digunakan untuk sarana pengajaran. Sebagian besar belum memanfaatkan aplikasi ini untuk salah satu sarana pengajaran. Beberapa pernah mencoba tapi kurang berhasil karena belum mengetahui cara yang efektif menggunakan aplikasi ini dalam pengajaran. Kemudian Tim Pengmas berusaha mencari nara sumber yang dapat membantu bagaimana agar pengajaran melalui LINE agar dapat berhasil. Disamping itu bagaimana membuat silabus sederhana untuk pengajaran di aplikasi LINE.

\section{Tahap Evaluasi}

Pada tahap ini tim Pengmas memberikan tugas membuat silabus sederhana yang dapat diaplikasikan ke LINE. Pada umumnya guru tak mendapat kesulitan membuat silabus sederhana ini

Target yang diharapkan dari kegiatan ini adalah: 1. Guru dapat mengganti pertemuan yang terlewatkan dengan menggunakan aplikasi LINE dengan cara memberikan catatan dan latihan, dan akan dibahas pada tatap muka dihari berikutnya. 2. Disamping itu, guru dapat memberikan materi tambahan yang lebih sulit untuk menghadapi USBN atau UNBK. 3. Guru juga dapat memonitor siswa dalam pengerjaan latihan ataupun ujian melalui aplikasi LINE. 4. 


\section{Suluah Bendang: Jurnal Ilmiah Pengabdian Kepada Masyarakat}

Vol.19, No.3, 2019

Syaadiah Arifin1, Hamzah Puadi llyas2, Aida Fitri Ani3

Pelajaran bahasa Inggris akan lebih menarik karena siswa tidak hanya mengerjakan latihan hanya dari LKS seperti selama ini.

Target capaian dari kegiatan pelatihan ini adalah diharapkan guru mampu membuat tahapan-tahapan pengembangan RPP/ lesson plan sederhana pada masing-masing skil dalam bahasa Inggris seperti: reading, speaking, listening dan writing yang akan diaplikasikan melalui LINE. Guru juga diharapkan lebih kreatif mencari bahan tambahan di link-link yang menyediakan materi pembelajaran bahasa Inggris.

\section{METODE PELAKSANAAN}

Kegiatan penyuluhan ini diadakan dengan cara diskusi interaktif, tanya jawab dan penjelasan dari nara sumber kepada delapan orang guru yang berasal dari SMP di daerah Cilamaya (SMP Babusallam Cilamaya, SMP Al Kautsar Cilamaya Wetan, SMPN I Cilamaya, dan SMP Muhammadiyah Cikampek) yang dikoodinir dan diadakan di Yayasan nonprofit Al' Kautsar pada tanggal 5-6 Juni 2019. Pelatihan diadakan dari jam 13.00-16.30. Peserta diundang melalui e-mail. Yang hadir hanya delapan (8) orang, karena pada saat itu sekaolah lagi libur panjang dan banyak guru yang berhalangan untuk datang ke pelatihan ini. Metode pelaksanaan PKM ini adalah dengan tatap muka langsung. Pada pertemuan pertama diadakan diskusi mengenai Blended Learning untuk mengetahui sampai dimana pengetahuan guru mengenai Blended Learning dan sejauh mana pengetahuan guru-guru mengenai aplikasi Line. Di pertemuan kedua masing-masing guru diberi tugas untuk menulis silabus sederhana yang akan didiskusikan bersama bagaimana mengaplikasikan lesson plan tersebut di aplikasi Line. Instrument penyuluhan menggunakan contoh lesson plan, power point presentation, diskusi interaktif, dan beberapa link yang dapat dipakai sebagai media pembelajaran online seperti YouTube dan British Council.

\section{HASIL DAN PEMBAHASAN}

Pengabdian kepada masyarat kali ini mengenai penggunaan aplikasi LINE untuk meningkatkan kemampuan siswa Sekolah Menengah Pertama. Kegiatan ini dilaksanakan dengan tatap muka langsung. selama dua hari. Dibawah ini adalah uraian dari kegiatan Pengmas:

\section{Pelaksanaan Kegiatan Hari Pertama}

Pada hari pertama diadakan diskusi mengenai yang apa dimaksud dengan Blanded Learning dan aplikasi LINE. Sebagian peserta cukup mengenal istilah- istilah tersebut. Selanjutnya dijelaskan beberapa step sederhana dalam melaksanakan Blended Learning dengan menggunakan aplikasi Line:

Step1:

Desain RPP/ lesson plan sederhana untuk target pengajaran dan praktik selama satu semester/ disesuaikan dengan rencana pengajaran. Pembuatan RPP sederhana bermanfaat bagi guru maupun siswa karena program akan semakin terarah dan mempunyai objektif yang jelas.

Step2:

Tetapkan jadwal untuk berlatih 2 kali per minggu atau disesuaikan dengan situasi dan kebutuhan siswa. Guru harus mendisiplinkan siswa untuk tepat waktu dalam mengerjakan tugas dan juga mengirimkan tugas yang diberikan. 


\section{Step 3:}

Atur siswa ke dalam kelompok yang lebih kecil. Jika didalam satu kelas terdiri dari banyak siswa, maka akan lebih efektif dibuat beberapa kelompok kecil. Setiap kelompok ada beberapa siswa yang lebih kemampuan akademisnya untuk membantu teman yang masih kurang. Kemajuan siswa juga akan lebih mudah dipantau bila dikelompokan.

Step 4:

Temukan sumber teori praktis yang cocok dengan silabus. Dalam hal ini guru harus meluangkan waktu untuk mencari bahan tambahan yang menarik melalui link-link yang bisa di dapat dari internet, atau memodifikasi bahan-bahan pelajaran agar lebih menarik.

Step 5:

Buat skala skor untuk evaluasi per sesi. Guru harus menyediakan rubric penilaian untuk setiap skil, atau dapat menggunakan rubric yang sudah ada dengan memberikan sedikit modifikasi.

Step 6:

Lihat dan bandingkan kemajuan per minggu. Guru harus mengontrol kemajuan siswa dengan mengadakan kuis atau tes. Jika tidak ada kontrol guru, program ini tidak akan berjalan dengan baik.

\section{Step 7:}

Berikan perhatian ekstra untuk siswa yang kurang. Karena kemampuan siswa berbeda beda, guru harus memberikan perhatian lebih kepada siswa yang kurang dengan cara memberikan latihan ekstra.

Step 8:

Bahas dan tanyakan soal-soal mana yang tidak dimengerti siswa saat megerjakan online pada saat tatap muka di dalam kelas.

Pada kesempatan ini tim PKM akan fokus memberikan pelatihan penggunaan aplikasi LINE untuk meningkatkan skil Speaking and Reading. Dipilihnya reading karena skil ini diujikan pada USBN dan UNBK. Dengan menggunakan aplikasi LINE guru dapat mengunggah soal-soal Reading, dan siswa mengerjakan di rumah. Guru akan memeriksa hasil kerja siswa dan membuat catatan mengenai kesulitan utama dalam mengerjakan soal-soal tersebut. Kesulitan tersebut akan dibahas dan diterangkan di sekolah pada saat tatap muka. Siswa dapat berlatih dirumah secara pribadi atau bersama teman. Guru juga dapat memberikan tes reading dan menginstruksikan siswa untuk mengerjakan di rumah dengan diberi batas waktu yang sudah disepakati. Sedangkan speaking diberikan juga melalui aplikasi LINE dikarenakan kurangnya waktu untuk berlatih pada saat tatap muka.

Cara mengajar skil Speaking di aplikasi LINE

Pertama guru disarankan membuat RPP/lesson plan sederhana (untuk keperluan mengajar di applikasi LINE) yang mengacu kepada silabus yang sudah ada. Dengan kata lain semua topik yang akan diajarkan disesuaikan dengan silabus yang sudah ada di sekolah. Sebagai contoh akan diambil tema Greetings sebagai topik. Di kelas akan diperkenalkan terlebih dahulu beberapa ekspresi menyapa (Greeting), dan beberapa hal yang berhubungan dengan topik yang akan dibahas diantaranya adalah: kosa kata, tata bahasa, dan berbagai contoh percakapan yang ada hubungan dengan Greetings. Karena keterbatasan waktu, tidak semua dapat berlatih di kelas, sedangkan percakapan membutuhkan latihan yang cukup. Untuk mengatasi hal ini siswa dapat berlatih di aplikasi LINE. 


\section{Suluah Bendang: Jurnal Ilmiah Pengabdian Kepada Masyarakat}

Guru akan membuat grup besar yang beranggotakan semua siswa dikelas IX, contohnya ada 40 siswa di masing-masing kelas. Kemudian grup besar ini akan dibagi bagi dalam bentuk grup-grup kecil yang beranggotakan 4 siswa, berarti ada 10 grup kecil. Kegunaaan dari membuat grup besar, agar semua siswa memperoleh informasi dari guru dan juga sebagai tempat sharing antar siswa dan guru.

Kemudian guru memberikan Link Youtube dan British Council dengan tema yang sama Greetings. Setiap anggota group membuka LINK ini dan mendiskusikannya. Sebagai latihan mereka harus membuat percakapan berpasangan atau pergrup tergantung situasi dari topik yang mereka lihat di YouTube. Setelah selesai mereka dapat memperagakan percakapan kepada guru mereka melalui Video Call. Setiap grup telah mempunyai jadwal masing-masing disesuaikan dengan kesepakatan bersama kapan mereka dapat memperagakan percakapan mereka melalui Video Call bersama guru mereka. Siswa juga dapat diberi tugas mengucapkan kata atau kalimat yang benar melalui Voice Note. Minggu berikutnya di dalam kelas guru mengajukan pertanyaan mengenai kesulitan yang dihadapi oleh siswa.

Guru juga dapat menerangkan grammar per kelompok kecil jika siswa mendapat kesulitan memahami salah satu bentuk tenses atau mengajarkan vocabulary dan pengucapan yang benar.

Melalui layanan Line dapat dilakukan pembicaraan 1 lawan 1 misalnya antara siswa dengan guru atau siswa dengan siswa lainnya, guru dapat berinteraksi dengan banyak siswa. Hal ini dapat dilihat dari diagram dibawah:

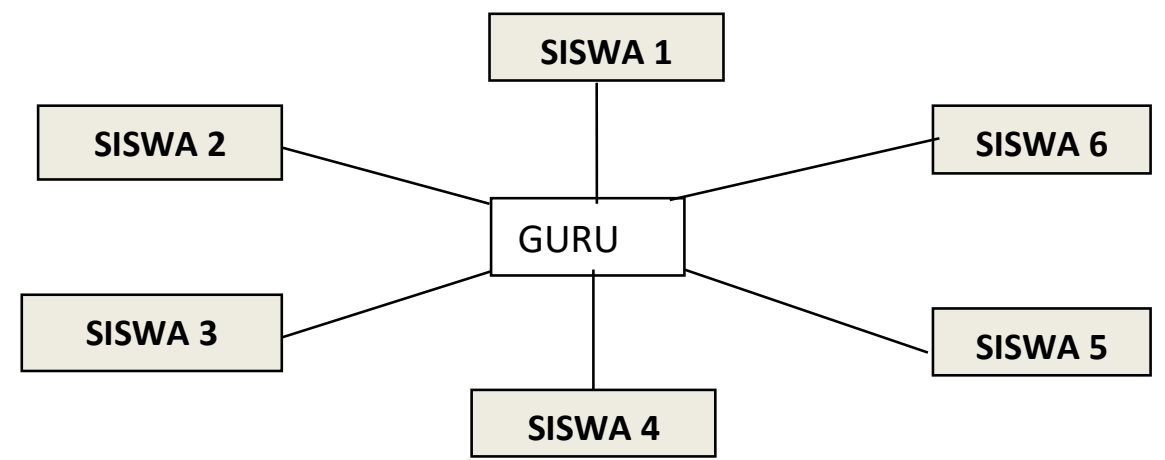

Gambar 1. Cara mengajarkan skil Reading di applikasi LINE:

Sama seperti mengajarkan skil Speaking mengajarkan skil Reading guru dianjurkan membuat RPP sederhana (untuk keperluan mengajar di applikasi LINE) yang mengacu kepada silabus yang sudah ada. Siswa tetap akan belajar dalam grup kecil. Di kelas guru tetap memberikan materi sesuai silabus yang ada, akan tetapi latihan tambahan akan diberikan di aplikasi LINE. Mereka tetap berlatih di buku LKS sekolah.

Permasalahan dengan Reading adalah terkadang soal-soal yang keluar di USBN dan UNBK jauh lebih sulit dari latihan-latihan yang ada di buku cetak ataupun LKS. Untuk mengatasi hal ini guru dapat memberikan latihan tambahan melalui aplikasi LINE. Guru akan membuat daftar mengenai bentuk soal apa saja yang sering keluar pada saat ujian, dan guru mempersiapkan latihan-latihan tersebut dan mengirimkannya ke masing-masing grup-grup LINE. Mereka berlatih bersama dan guru dapat membahas latihan per grup sesuai dengan jadwal yang sudah ditentukan sebelumnya. 
Guru dapat memberikan kuis atau tes kepada siswa dengan jadwal yang disepakati bersama. Sebagai contoh guru akan memberikan tes Reading dan mengirimkan ke grup besar. Siswa diberi waktu tertentu untuk menyelesaikan tes tersebut. Setelah waktu habis, guru akan memerintahkan mengirimkan jawaban mereka segera ke guru. Pada pertemuan berikutnya guru akan membahas soal tersebut bersama sama.

Hal yang paling utama memberikan pengajaran tambahan melalui LINE, guru harus kreatif dan rajin dalam memberikan latihan-latihan yang menarik siswa untuk belajar lebih serius.. Penjelasan diatas adalah contoh-contoh sederhana membuat dalam latihan yang akan dikerjakan siswa diaplikasi LINE. Presenter juga memberikan beberapa contoh rencana pembelajaran atau RPP. Sebelum workshop hari pertama berakhir, guru diberi tugas membuat RPP atau rencana pembelajaran dengan menggunakan aplikasi LINE. Mereka diberi kebebasan untuk memilih skil apa saja untuk latihan ini, dan akan dibahas di hari kedua.

Dengan adanya kegiatan pelatihan penggunaan aplikasi LINE dalam pengajaran bahasa Inggris, guru dapat membuat lesson plan yang menarik yang akan diterapkan dalam memberikan pelajaran dan latihan tambahan. Guru juga dapat memotivasi siswa untuk menjadi pembelajar mandiri, karena siswa dapat mengerjakan soal-soal bahasa Inggris secara mandiri tidak dibatasi waktu dan tempat. Pembelajar mandiri (autonomous learners) mengacu kepada kemampuan seseorang dalam bertanggung jawab atas proses belajar sendiri (Holec, 1981). Hal ini sangat penting bagi siswa untuk sukses dalam proses belajar mereka. Pelajaran bahasa Inggris akan lebih menarik karena siswa tidak hanya mengerjakan latihan hanya dari LKS ataupun buku teks yang didapat dari sekolah seperti selama ini yang mereka lakukan. Melalui aplikasi Line siswa dapat mengerjakan soal-soal dimanapun mereka berada.

Perkembangan teknologi yang modern dimasa sekarang ini separti menggunakan mobile phone dan sumber daya pembelajaran melalui online banyak mengubah pendekatan pedagogi dan meningkatkan hasil belajar siswa (Govindasamy, 2001). Yang pada akhirnya akan memberikan keuntungan baik bagi guru maupun siswa.

\section{KESIMPULAN}

Dari pelatihan singkat selama 2 hari kami dapat menarik kesimpulan pemanfaatan aplikasi LINE dapat membantu guru dalam media pengajaran. Guru peserta pelatihan memberikan tanggapan positif karena akan didapat manfaat yang berguna dari aplikasi LINE sebagai salah satu sarana pembelajaran dalam membantu siswa meningkatkan kemampuan bahasa Inggris mereka. Implementasi aplikasi Line membutuhkan kreativitas dan dukungan dari guru untuk memberikan link-link tautan materi Bahasa Inggris untuk dipelajari oleh siswa. Kegiatan harus diatur dan dilakukan secara efektif antara siswa dan guru. Ini sejalan dengan ide-ide modern pembelajaran aktif yang berpusat pada siswa (Fresen, 2007).

\section{DAFTAR PUSTAKA}

Bryan, A., \& Volchenkova, K. N. (2016). Blended Learning: Definition, Models, Implications for Higher Education. Bulletin of the South Ural State University Series "Education. Education Sciences," 8(2), 24-30. https://doi.org/10.14529/ped160204

Fresen, J. W. (2007). A Taxonomy of Factors to Promote Quality Web-Supported Learning 1 Jill W. Fresen (PhD), University of Pretoria, South Africa. 6(3), 351-362.

Friesen, N. (2012). Definición de Blended, Learninghttp://www.umng.edu.co/documents/63968/76126/11.pdf. (August), 1-10. Retrieved from http://learningspaces.org/papers/Defining_Blended_Learning_NF.pdf 
Govindasamy, T. (2001). Successful implementation of e-Learning Pedagogical considerations. Internet and Higher Education, 4(3-4), 287-299. https://doi.org/10.1016/S10967516(01)00071-9

Holec, H. (1981). Autonomy and Foreign Language Learning. In Communicative Competence.

Ramadan, R. (2018). 5 Keunggulan LINE Yang Bikin Anak Muda Menjadikannya Aplikasi Favorit Selain Instagram - Semua Halaman - Hai.Grid.ID. Retrieved October 28, 2019, from https://hai.grid.id/read/07606907/5-keunggulan-line-yang-bikin-anak-mudamenjadikannya-aplikasi-favorit-selain-instagram?page=all

Tamimuddin, M. (2017). PEMANFAATAN MATHEMATICS MOBILE LEARNING DALAM PEMBELAJARAN MATEMATIKA. LIMAS, 18. Retrieved from limas.p4tkmatematika.com 